Relations industrielles

Industrial Relations

\title{
Making Capitalism Safe: Work Safety and Health Regulation in
} America, 1880-1940, by Donald W. Rogers, Champaign: University of Illinois Press, 2009, 296 pp., ISBN: 978-0-252-03482-4.

\section{Isik U. Zeytinoglu}

Volume 68, numéro 2, printemps 2013

URI : https://id.erudit.org/iderudit/1016324ar

DOI : https://doi.org/10.7202/1016324ar

Aller au sommaire du numéro

\section{Éditeur(s)}

Département des relations industrielles de l’Université Laval

\section{ISSN}

0034-379X (imprimé)

1703-8138 (numérique)

Découvrir la revue

Citer ce compte rendu

Zeytinoglu, I. U. (2013). Compte rendu de [Making Capitalism Safe: Work Safety and Health Regulation in America, 1880-1940, by Donald W. Rogers, Champaign: University of Illinois Press, 2009, 296 pp., ISBN: 978-0-252-03482-4.] Relations industrielles / Industrial Relations, 68(2), 343-344.

https://doi.org/10.7202/1016324ar

Tous droits réservés @ Département des relations industrielles de l’Université Laval, 2013
Ce document est protégé par la loi sur le droit d'auteur. L’utilisation des services d'Érudit (y compris la reproduction) est assujettie à sa politique d'utilisation que vous pouvez consulter en ligne.

https://apropos.erudit.org/fr/usagers/politique-dutilisation/ 
fashion multinational became friends and worked together to improve relief in tragic circumstances.

If I have one quibble it is that the book lacks an index although I am led to believe that this is to be made available on the publisher's website, from which an E-book version can also be downloaded.

The Last Night Shift in Savar story is a major contribution to understanding and hopefully addressing the persistent health and safety malaise which continues to dog the RMG in Bangladesh in 2013. Fresh calls for prevention and improved worker compensation have seen the focus now shift to North American brands which have been implicated in a number of recent fires. For these companies their drive to use cheap labour has now come at its true cost. For those US and Canadian students of globalization wishing to put their theory into practice in their efforts to mobilize support for those demands raised by Bangladeshi activists, unions and NGOs in the wake of the Spectrum disaster, this book is an absolute must read.

P.S.: After this review was accepted by $R I / I R$, there have been several additional incidents involving loss of life in Bangladesh, making all the issues raised in Doug Miller's book even more urgent.

\section{Bruce Spencer}

Athabasca University

\section{Making Capitalism Safe: Work Safety and Health Regulation in America, 1880-1940}

by Donald W. Rogers, Champaign: University of Illinois Press, 2009, 296 pp., ISBN: 978-0252-03482-4.

This book is a comparative analysis of industrial safety and health regulation in six states in the U.S. It starts with the experience in Wisconsin in 1880s and examines how the regulation evolved in this state. The author compares Wisconsin's labour law experience with Ohio, California, New
York, Illinois, and Alabama. Although the author does not explain why these states are selected, early industrialization and strong labour unions in these jurisdictions make them a good choice for the comparative analysis.

In 1910 Wisconsin is looked upon as the Bismarckian Germany of the United States, enacting progressive labour laws that influence the rest of the country. History treats Wisconsin's Industrial Commission as a pioneer in making health and safety regulations in the form of administrative rules, rather than piecemeal laws, and for its national influence in guiding the future State and Federal regulation of occupational safety and health. The Commission is also considered a minion of business interests. The author asks whether other states adopted Wisconsin Industrial Commission model; what their powers were; and whether they equalized business and labour influence in policy proceedings, or succumb to business interests. To answer these questions, the author reappraises progressive safety and health legislation in the U.S. conducting a six-state comparative analysis.

There are nine chapters and an epilogue in this book. Chapter 1 examines state departments' heritage in nineteenth-century common law and factory legislation. Chapter 2 examines their foundation in progressive labour law politics and public utility law reform. This is followed, in Chapters 3-5, by detailed analyses of state labour departments' educational, safety code-making, and enforcement functions in the 1910s, and, in Chapters 6-8, in the 1920s and 1930s. Chapter 9 examines the occupational disease work. The book concludes with the demise of state laws and the ascendency of the Occupational Safety and Health Act (OSHA) era.

Nineteenth-century common law rules relegated most accident liability to workers. Historians have long regarded progressive workers' compensation laws as the turning 
point in work accident law that ended the rule of common law and instituted a new legal regime that made employers' responsible for workplace injuries. This book argues on the contrary and shows that 'safe place statutes' in Wisconsin, Ohio, and California enlarged enterprise responsibilities that existed under common law, requiring employers to install the best protection economically and technically feasible.

I was particularly interested in Chapter 9 titled, 'the troubled campaign against occupational disease'. Hygiene in the work environment and ventilation were the first safety precautions that took place in workplaces. With the industrialization, illnesses due to using lead, phosphorus and toxins emerged. Medical advances and the political environment in Wisconsin in the early 1900 s to 1940s contributed to the acceptance of the relationship between workplace environment and certain occupational illnesses, but few other states' programs followed the example of Wisconsin. A uniform national occupational disease policy emerged only after the passage of the 1969 Coal Mine Health and Safety Act and the 1970 OSHA. The conservative political environment of the 1970s and afterwards made OSHA and its administration ineffective in dealing with diseases and illnesses that emerged. The author shows that the OSHA system apparently failed to reduce accident and disease levels. The book concludes that the OSHA as a legislation could have brought a uniform occupational safety and health policy in the U.S., but at the end, the administrative bureaucracy and the conservative political environment did not allow the legislation to fulfil its potential. I found this chapter insightful; particularly in explaining how occupational diseases were detected but then how any improvement in workers' health was hampered by employers' resistance.

I found the book interesting and informative. Perhaps historians in Canada might say that the history on the development of occupational health and safety laws in the six states in the U.S. resembles the experience here in Canada. Without a background in labour history, I am unable to make such claims. However, I can say that this was an impressively detailed and well-documented record of how state laws on occupational health and safety evolved into the national level OSHA, and how trade unions' and progressive politicians' efforts contributed to this progress while employers attempted to limit the legal requirements and campaigned against the acceptance of (todays' well-known) occupational diseases and employer responsibilities in this process. I strongly recommend this book to those interested labour history, history of law and occupational health and safety.

\section{Isik U. Zeytinoglu}

McMaster University

\section{Trajectoires des modèles nationaux : État, démocratie et travail en France et en Allemagne}

sous la direction de Michel Dupré, Olivier Giraud et Michel Lallement, Bruxelles : Peter Lang, 2012, 398 p., ISBN 978-90-5201-863-8.

La production de comparaisons internationales est souvent faite sur le mode de la mise en concurrence des législations nationales et des territoires, dans une perspective normative évidente. L'ouvrage dirigé par Dupré, Giraud et Lallement s'inscrit cependant dans autre logique qui a une longue tradition de comparaisons des conditions de travail et d'emploi entre la France et I'Allemagne dans une approche comparée institutionnaliste. Dans le cadre de la construction européenne, ces deux pays sont souvent nommés le « tandem » francoallemand. Pourtant au plan économique et social, les travaux d'analyse comparée font ressortir que ces deux pays ont des trajectoires institutionnelles profondément différentes, ce qui rend la comparaison d'autant plus intéressante. C'est le paradoxe que l'on retrouve au cœur de tout travail de comparaison entre les deux pays. 